\title{
Utilizing Literature Circles for Enhancing EFL learners' Reading Comprehension Skills
}

\section{$\mathfrak{B y}$}

Dr.Hanaa El-Baz Ibrahim Lecturer of Curriculum \& TEFL Faculty of Education, Damietta University
Saad Kamel Mohammed Ahmed A Senior Teacher of English 


\section{Introduction}

Language is supposed to be one of the most indispensable means of communication between people. Everybody should use language to convey messages or feelings whether verbally or in a printed form. It is believed that the English language is used in all fields of life beginning with politics and ending with learning and teaching. So, English is considered the first worldwide language.

Baron (2001, p. 36) assures that there has been recently an increasing and rising growth in the total number of people around the world who communicate with each other using English as a second language. Similarly, Harmer (2001, p. 14) claims that many countries are focusing on learning English as a second or foreign language and it becomes the "Lingua Franca" for business relations among all nations. Thus, lots of Arab countries including Egypt provide strategies and programs in order to teach English and use it in a meaningful way.

Being one of the four major language skills, reading plays an important role in determining students' educational future and it is the most important and essential skill to educational achievement and academic success (Gisler \& Eberts, 2009). The National Center for Educational Statistics [NCES], (2005, p. 2) defines reading as "an active and complex process that involves understanding written text, developing and interpreting meaning, and using meaning as appropriate to the type of text, purpose, and situation". Besides, Paris and Hamilton (2008) emphasize that without comprehension, reading means reproducing and repeating the language sounds and reciting text is simply memorization and oral drill.

Similarly, Gunning (2008) states that comprehension is the main purpose for reading. It determines whether the text is understood. Students need comprehension to understand words, interpret sentences and words, understand full texts, and to use the information that is gained. In order to comprehend, students need to be able to interpret, read fluently, and know the vocabulary.

Edmonds, et al., 2009; Williams, 1998, 2000, as cited in Vaughn et al., (2011, p. 940) assures that even though understanding a reading text is so essential to the learning process, lots of students find this skill challenging. Grasping the main idea of the text is a perplexing area for students as they frequently fight with reading for understanding. Senior students are not equipped to realize complex complicated texts. Students who know at elementary levels are subject to be incompetent to keep up with the required skills (Bransford, Brown, \& Cocking, 1999, as cited in Murphy, Wilkinson, Soter, Hennessey, \& Alexander, 2009, pp. 740-741). 
According to Vaughn et al. (2011), skillful readers have the ability to detect the structure of the text, understand, and make their own connections to impressions and thoughts, and review through words or writing. Such approaches can be improved to keep comprehension skills.

Many researchers such as Reichert (2005) and Harmer (2001) suggest that innovative concepts related to teaching reading may be required to replace the traditional ones. Among these innovative strategies is the literature circles strategy. Daniels (2002) confirms that literature circles are a form and practice of literature in a meaningful way. Small groups of students are formed and they are encouraged to read with a focus and then report on and discuss what they read, determining for themselves what is important and why. More than that Hill, Noe, and King (2003) adds that during discussion and conversation, each student undertakes and assumes a certain role that corresponds to precise and specific cognitive tasks, thereby providing a supporting a basis for the discussion. The classroom teacher offers help, care, and support to students as they apply strategies while interacting and cooperating with each other and with the text. A long-term goal of this approach is the selfregulated use of these strategies to foster and consolidate comprehension.

Literature circles give students a chance to select what to read and an opportunity to talk to each other, on a weekly basis, about a particular book. This encourages free expression of readers' opinion, and gives an opportunity to share ideas that students normally do not do in a whole group classroom setting. Research indicates not only have literature circles increased reading comprehension skills, but also this activity has encouraged students to become active listeners and risks takers while increasing their communication skills, and developing more of their thinking abilities ( Brown, 2002).

Furthermore, literature circles also give students the opportunity to create connections between texts and personal experiences, monitor and take ownership or their own learning, as well as have the opportunity to listen to other group members' interpretations of the same text. Moreover, it provides students with an avenue to discuss and share thoughts and opinions. All of this adds to their enjoyment of the text (Zemelman, Daniels, \& Hyde, 1993, cited in Keulen, 2011).

\section{Review of literature}

\subsection{Definition of Literature Circles}

The term, literature circle can be defined as small groups of students reading the same book and communally constructing meaning as they respond, discuss, and think about the text (Hillier, 2005; Marshall, 
2006; Nolasco, 2009, p.8; Olsen, 2007; Prillaman, 2008; Sousa 2011, p.8).

Moreover, Casey (2008, cited in Gall, 2010) defines literature circles as a small group of students reading the same work of literature and working with peers while performing discussions. It is a combination of individual reading and collaborative learning (Tracey \& Morrow, 2006). It is a teaching method differentiated in terms of implementation (Tomlinson \& Strickland, 2005). It is theoretically based on constructivism and socio-cultural theory (Hsu, 2004; Tracey \& Morrow, 2006).

Above all, Maraccini (2010) defines literature circles as "Just one strategy that incorporates the use of student dialogue and conversation to improve comprehension and reading skills" (pp. 25-26). Moreover, literature circles could be one intervention that has the potential of introducing a variety of input for challenging students' thinking and developing their oral production. Finally, literature circles could be considered as an effective cooperative learning strategy that promotes students' interest in reading while enhancing their self-perceptions (Hillier, 2005; Olsen, 2007; Prillaman, 2008; Nolasco, 2009).

\subsection{Characteristics of Literature Circles}

Literature circles are different from other kinds of group discussion; they are distinctive in that they incorporate various learning features in literary instruction. Daniels (2002, p.18) introduced the characteristics of LCs including the following eleven key elements, each of which adds to the success of LCs.

1) Students choose their own reading materials. "The deepest spirit of literature circles comes from independent reading" (Daniel, 2002).Unlike traditional classrooms, the students are free to choose what they want to read and discuss it together in group (Johnson, 2001).

2) Small temporary groups are formed based on text choice. Literature circles groups are formed by students who wish to read the same text. These groups have different abilities and views. Group sizes can range from two to six, although seems to be four or five and this number is the best to enliven discussion. When the teacher gives the students time to form the groups and solve the problem, finally the groups are ready to work (Reid, 2002; Slavin \& Smith, 2009).

3) Different group read different texts; obviously, when students are given a genuine choice of what to read. Not everyone pick a same text.

4) Student groups meet on a regular, predictable schedule to discuss reading. To the success of literature circles, groups meet on a systematic, anticipated plan to discuss their reading. EFL Literature circles require a good agreement of student training time; thus, a teacher must be ready to 
commit this schedule to get positive results. The teacher should not even consider trying literature discussion circles as a "one time" classroom activity. Literature circles promote a natural integration of reading skills and students get better at integrating these skills as they practice using them over and over during the school semester; thus, it is important to hold literature circles on a steady base (Kim, 2004).

5) Written and drawn notes are used to guide students' reading and discussion.The Role Sheets support each member of a small reading group to read a story and to prepare their thoughts, notes and what they are going to talk about in their group for a group discussion. In this way, students are learning that there are reasons for reading any given text (Hill \& King, 2003).

6) Students generate discussion topics. The role sheets enable students to use topics for discussion when talking about the reading text in their literature circle groups, and ensure that students are having meaningful discussions without teacher directed ones (Raman, 2004).

7) Group meetings are open, natural conversation about books, so personal comments are welcome. Students share their opinions and ideas about the texts read in group discussions, also these meetings allow them to share laughing with one another because this is the natural conversation in literature circles (Haddon, 2003; \& Thornbury, 2006).

8) Discussion roles are rotated.

9) The teacher is a facilitator, not a group member or an instructor.The teacher's role in literature circles classroom is to be an observer, facilitator, mediator and helper for each group's discussions. Also, the teacher sometimes shares in opinions, ideas when she wakes in class (Raman, 2004).

10) Evaluation is conducted by teacher observation and student evaluation.

11) Playfulness and fun are maintained in the classroom. In literature circles, the students feel excited and the group discussions have a soul of the competition (Gilmore \& Day, 2006).

Upon finishing books, readers share with others, and new groups form around new reading choices. After the groups finish their discussions, the teacher may then ask the groups to produce something reflecting the group's work. For example, each member in the up writes a report about the attractive section in the story and read it in a loud voice in front of the class (Zeger, 2006).

\subsection{Benefits and Advantages of Literature Circles}

Zieger (2002) demonstrated many positive impacts of using literature circles on her learners. By participating in literature circles, learners were given opportunity to read and discuss in groups. These 
discussions help learners gain understanding of the story. In addition, the learners learned to summarize, make inferences and connections, develop their vocabulary, ask relevant questions, and provide appropriate responses. In the study of non-fiction, Pitman (1997) reported that literature circles enhanced learners' reading skills, gained selfconfidence, and improved oral and written communication.

Furthermore, Pitman (1997) concluded that literature circles improved student attitudes toward reading, improved comprehension, and developed self-confidence and cooperation. Literature circles encourage students to become active listeners and risk takers while increasing their communication skills and help develop more of their thinking abilities (Brown, 2002). Brown also reported that literature circles can give students an opportunity to raise questions, argue, reflect, negotiate, and develop new meaning while working together.

More than that, through the use of literature circles, students learn various roles and reading strategies. The benefit to the student is that they are able to learn and use these strategies on their own during the course of using literature circles. The strategies can then be incorporated into other subject areas. Some of the strategies that students enact in literature circles are

Prediction, construct visual images, create connections to personal experiences and other texts, monitor their reading and whether it makes sense, solve word and text-level problems in flexible ways, summarize as they go, argue with the author, and evaluate content and writing style (Blum et al., 2002, p. 101).

In addition to that, Literature circles can address the challenges of the inclusive classroom and promote self-determination (Blum et al., 2002). Literature circles are becoming a strategy to address differentiating instruction in a classroom. Struggling students are apprehensive to read in a large reading group and literature circles give struggling readers the opportunity to discuss and engage in conversation on a smaller scale. Blum et al. (2002) stated that literature circles can help students with special needs increase their perceptions of their own abilities to read.

At the same time, Lin (2004) suggests there are four main benefits for using literature circles. They are: stronger reader-text relationships, improved classroom climates, enhanced degrees of gender equity and understanding and, lastly, a learning environment more conducive to the needs and abilities of English language learners. Lin suggests that "readers are those who not only recognize words while reading, but for which the text resonates through association with related life experiences or literary experiences which are familiar to other members of the same learning community" (p. 24). 
Likewise, Almasi (1996) indicated three dimensions of benefits of engaging in literature discussions: cognitive, social-emotional, and affective benefits. In other word, students develop higher levels of critical thinking skills when engaging in reading matters and connecting what they learn to their life experiences, which is an intellectual endeavor that results in a cognitive benefit. Students may receive social benefits from LCs when they become more skilled in interpreting texts by interacting with group peers. In addition, the LCs also benefit learners in increasing their motivation for reading literature, because students are given more freedom to talk about their reading work, and share their feelings and thoughts in a pleasurable learning environment.

In brief, Literature circles offer many profits for both students and teachers. These benefits are explained as following:

\subsubsection{The benefits of literature circles for students}

Most students who have taken part in literature circles will explain it is not the same type of reading class. They may even mention it is more "fun." One of the benefits of using literature circles is the reader is empowered because the reader is allowed to participate in the decisionmaking process (Blum et al., 2002). Daniels (2006) explained that by using choice in literature circles, students can experience success and avoid frustration by choosing their own books and friends in the group. As a result of providing choice and students feeling successful, Casey (2008) noted that literature circles have the potential to help motivate students who are disengaged and frustrated readers. This motivation can be a factor because the use of literature circles helps to meet a variety of literacy needs and interests.

Another benefit to using literature circles is that they help to build community in the classroom (Lin, 2004). Students not only learn from each other, they also learn how to communicate their ideas and, possibly with the help of the teacher, they learn social skills, such as how to handle disagreements. Overall, Dalie (2001) believes literature circles help create "real" readers because they encourage students' real thoughts and reactions to the text (p. 101). Their opinions matter, so they feel validated.

\subsubsection{The benefits of literature circles for teachers}

Aside from students, teachers also benefit from the use of LCs in a variety of classrooms. Leal (1993) stated that literature discussion in small groups offers a window for reading teachers to hear students' voices, to understand students' thoughts about books, and to monitor their reading progress, as well as to assess their textual comprehension, which may facilitate classroom teaching and enrich literacy learning in order to 
meet learners' complex needs of reading. Martinez-Roldan and LopezRobertson (1999) suggested that teachers should value the differences in student's dynamic responses to literature and facilitate a critical dialogue by encouraging them to share experiences and think thoughtfully through storytelling. Kelley and Clausen-Grace (2007) stated the job of the teacher has shifted, "Your role in literature circles is to teach students how to think about what they are reading and how to have a quality conversation about the text" (p.10).

Considering the importance of LCs in reading, Owens (1995) cited in Stabile (2009) discussed nine key rationales depicting the value of LCs for literacy instruction:

1. To promote a love for literature and positive attitudes toward reading.

2. To reflect a constructivist, child centered model of literacy.

3 . To encourage extensive and intensive reading.

4. To invite natural discussions that lead to student inquiry and critical thinking.

5. To support diverse response to texts.

6. To foster interaction and collaboration.

7. To provide choice and encourage responsibility.

8. To expose children to literature from multiple perspectives.

9. To nature reflection and self-evaluation (1995, p.3).

\subsection{Literature circles and reading comprehension}

Whittaker (2012) declares that literature circles can be effective and efficient, for refining comprehension, pleasure and delight of reading which could enhance motivation Harvey and Goudvis (2000) and Keene and Zimmerman (1997) have identified seven comprehension strategies that may be used in Literature Circles. These strategies are: making connections, questioning, inferring, visualizing or using mental imagery, determining importance, synthesizing, and monitoring.

Research indicated that participation in literature circles also led to an improvement in reading skill. According to McElvain (2010), if students took part in literatures circles and received some strategic skill training, their understanding improved. Students used the strategic skills they had learned when they were in their literature circles. This was true for both struggling readers as well as proficient readers. In a study done by Briggs (2010), all the students who participated in a literature circle were successful when given an assessment of the text they had discussed. Briggs suggests this is because of the discussions students had over the text before the assessments were administered Students who participated in literature circles made up to one year's worth of growth during the study. 
Thus, literature circles provide students the chances to encounter in small groups to talk and share their understandings about the book they are reading (Harvey \& Daniels, 2009; Harvey \& Steineke, 2004; Day, Spiegel, McLellan, \& Brown, 2002). As a consequence, students begin to think on a deeper level about what they are reading, share their thoughts, feelings, and questions in a small non-threatening atmosphere (Daniels, 2002; Day, Spiegel, McLellan, \& Brown, 2002). Furthermore, through these small peer-led discussions, students are able to comprehend more than they could alone (Day, Spiegel, McLellan, \& Brown, 2002). As the procedure grows over time, students become good readers, begin to feel a sense of enablement through literature, and eventually take concern for their own learning (Daniels, 2002; Day, Spiegel, McLellan, \& Brown, 2002; Stein, \& Beed, 2004).

As previously stated, literature circles are specially designed to strengthen reading comprehension skills (Huber, 2001). However, reading comprehension can be misunderstood in teaching. We often do not teach it but merely measure it. When we give students a story to read and ask them questions about it we are not teaching them how to comprehend, but are merely checking if they did comprehend (Day et.al, 2002).

Furthermore, McElvain proposed in his study that many "at-risk English learners" in the experimental classes made significant progress in reading comprehension after participating in literature circles for 9 months. This literature-circle base curriculum also increased learners' confidence and retention of important ideas from their reading (McElvain, 2005, as cited in Sai \& Hsu, 2007).

Given the importance of the literature circles strategy in developing reading comprehension skills, some researchers were interested in investigating the strategy. This concern exhibited itself in conducting a number of studies to investigate the effectiveness of the literature circles strategy.

Jacobs (2015) decided how literature circles affect reading comprehension and student enthusiasm towards reading. After gathering and examining the data over the course of three weeks, the researcher found out that the implementation of literature circles improved student motivation towards reading and deepened comprehension. The results indicated that students benefited from selecting their own books, roles, timetable, and discussion topics.

Salata (2015) determined the impact of using literature circles on special education and reading comprehension. Three data collection methods were implemented, including a post-test, student interviews, and 
an observational checklist with field notes. Data collection determined that literature circles may have been one factor that fostered mastery of content while reading stories by Poe.

The purpose of Rascher's study (2015) was to explore the impact on seventh-grade students with decoding deficits who participated in novelbased literature circles on a reading comprehension assessment as compared to a similar control group. The researcher observations indicated that literature circles can be a valuable component to reading instruction. Further research in this area should explore whether literature circles can improve reading comprehension when incorporated with more explicit reading comprehension instruction.

Similarly, Chiu (2010) tried to find out the effectiveness of using Literature Circles on EFL junior high students' English reading comprehension. This study also was planned to appreciate students' views of literature circles mid to provide suggestions for reading facilitators. The results of this study recommend that literature circles did help students better understand the stories and it did help to improve their reading comprehension to a definite degree. Due to the participation in literature Circle, students have shown more motivation for learning, more eagerness and excitement to transfer their attitudes, and more respect for various points of view from peers.

The purpose of Anderson' study (2012) was to improve a comprehensive understanding of the effects of the implementation of literature circles in an ELL classroom. Literature circles were implemented each day over a nine-week period. Questionnaires were given to the students before and after the implementation of literature circles. The results of this study were that the implementation of literature circles positively affected students' perceptions of reading, and the implementation of literature circles improved standardized reading test scores.

There were also many other studies that dealt with literature circles in developing reading comprehension skills like Brown (2002), Maraccini (2010), Hamilton (2002), Medrano (2013), Lin (2013), Jacobs (2015) and Tugman (2010).

\section{Commentary}

It is clear from reviewing the previous studies related to the effectiveness of literature circle Strategy in EFL skills that literature Circle strategy proved to be effective in improving reading comprehension, critical reading as well as attitudes towards reading. Also, Literature circle discussions were so effective in developing creative reading and literature appreciation. Moreover, these studies 
described different assessment tools as reports, surveys, interviews, preposttests, activities that were so helpful in the current study.

\section{Conclusions}

Literature circles presented a unique opportunity to combine a wide range of effective instructional practices in one activity, integrating group discussion, scaffolding, collaborative learning, critical thinking, authentic assessment, and constructivism all in one seem less bundle. The literature circles strategy had superiority over the traditional method in teaching English language.

Furthermore, literature circles provided students with a better learning environment which was reflected on their achievements as well as their positive attitudes toward studying English. Learning was more learner-centered as students took responsibility of their own learning. Similarly, using literature circles developed the cooperative learning within the same group and competition with other groups. Therefore, shy students and low-achievers became more motivated to participate and interact. It was found that the type of instruction that a student received affected reading comprehension and attitudes towards studying English. More recent research highlights the importance of engagement processes in facilitating reading comprehension and attitudes. Therefore, this approach needed to be taught directly as students learn to read; and this direct instruction needs to continue in different forms. Future designers of similar programs therefore, should put these factors into consideration. Effective techniques of teaching should always be supported by effective design plans and feasible strategies for application. 


\section{(References)}

Almasi, J. (1995). The nature of fourth graders' sociocognitive conflicts in peer-led and teacher-led discussions of literature. Reading Research Quarterly, 30 , 314-351. http://literaturediscussion.weebly.com/uploads/9/4/6/1/9461351/the _nature_of_fourth_graders_sociocognitive_conflicts_in_peer_led_ and_teacher_led_discussions_of_literature.pdf.

Anderson,A.R.(2012). Implementing Literature Circles: AN Experimental Study In An English language Learners 'Classroom. Doctor of Philosophy, School of Education, Capella University. Retreived July 8,2014 from: ProQuest Dissertation and Theses Database (UMI No. 3523558).

Baron, N. (2001) Alphabet to Email: How Written English Evolved and Where it's Heading. London: Routledge. Available: www.questia.com.

Blum, T., Lipsett, L, \& Yocom, D. (2002) Literature circles: A tool for self determination in one middle school inclusive classroom. Remedial and Special Education, 23 (2), 99-108.

Briggs,S.R.(2010). Using Literature Circles to Increase Reading Comprehension in Third Grade Elementary Students. Master of Science in Education, School of Education and Counseling Psychology, Dominican University of California. Available at:http://eric.ed.gov/?id=ED511091.

Brown, B. A. (2002). Literature circles in action in the middle school classroom. Georgia College and State University. (ERIC Document Reproduction Service No.ED478458).

Dalie, S. O. (2001). Students becoming real readers: Literature circles in high school English classes. In B.O. Ericson (Ed.) Teaching reading in high school English classes. Urbana, IL: National Council of Teachers of English. (ERIC Document Reproduction Service No. ED 458 526).

Daniels, H. (2002). Literature circles: Voice and choice in book clubs reading groups. Portland, ME: Stenhouse.

Day, J., Spiegel, D., McLellan, J., \& Brown, V. (2002). Moving forward with literature circles. New York, NY: Scholastic.

Gall, M. (2010). How does the implementation of literature circles influence student achievement and attitudes towards reading in the classroom? (Master Thesis). Southwest Minnesota State 
University. Retreived September 9,2014 from: ProQuest Dissertation and Theses Database (UMI No. 1485298).

Gilmore, D. P., \& Day, D. (2006). Let's read, write, and talk about it: Literature circles for English learners. In T. A. Young \& N. L. Hadaway (Eds.), Supporting the literacy development of English learners: Increasing success in all classrooms (pp. 194-209). Newark, DE: International Reading Association.

Gisler, P., \& Eberts, M. (2009). Top ten ways to improve reading skills, viewed 29th June 09. TU http://school.familyeducation.com/top10-ways/improve-reading-skills/38329.htmlUT.

Gunning, T. G. (2008). Creating literacy instruction for all children (6th ed.). Boston: Allyn\& Bacon.

Harmer, J. (2001). The practice of English language teaching,3rd edition, Pearson Education Limited, England: Essex.

Harvey, S., \& Daniels, H. (2009). Comprehension and collaboration. Portsmouth, NH: Heinemann.

Harvey, S., \& Goudvis, A. (2008).The primary Comprehension Toolkit : Language and Lessons for Active Literacy :Teacher's Guide. firsthand An imprint of Heinemann.

Hill, B., Noe, K., \& King, J. (2003). Literature circles in the middle school: One teacher's journey. Norwood, MA: Christopher-Gordon Publishers.

Hillier, M. A. (2004). Implementation of literature circles in a rural high school English school: One teacher's journey of changing student attitudes toward reading. Doctoral dissertation, University of Southern California, 2004). Dissertation Abstracts International, 13(2), 132.

Hsu, T. (2004). Reading without teachers: Literature circles in an EFL classroom. (ERIC Document Reproduction Service No.ED492558).

Huber, M. (2001). Literature circles; using student interaction to improve reading comprehension. Huntington Beach, CA: Creative Thinking Press, Inc.

Jacobs, M. (2015).Using literature circles to increase reading comprehension and student motivation. Master of Arts in Reading Education, Department of Language, Literacy, and Sociocultural Education ,College of Education, Rowan University. Available at: 
http://rdw.rowan.edu/cgi/viewcontent.cgi?article $=1567 \&$ context $=$ et d.

Johnson, G.N. (2001). "Literature discussion in the elementary school classroom. Developing cultural understanding" Multicultural Education, 8, 1, 33-36.

Keene, E. O. \& Zimmerman, S. (1997). Mosaic of thought: teaching comprehension in a reader's workshop. Portsmouth, NH: Heinemann.

Keulen, B.J. (2011). Literature Circles: Comprehension And Engagement Effects of Literature Circles on Comprehension and Engagement. Master of Science in Education, Southwest Minnesota State University Education Department. Retrieved July 9, 2016 from: http://www.k8acesscenter.org/training_resources/udl/diffinstructio $\underline{\text { n.asp }}$

Kim, M. (2004). Literature Discussions in Adult L2 Learning. Language and Education, 18(2), 145-166.

Lin, C. (2004). Literature circles.Teacher Librarian, 31(3), 23-25. Retrieved

from http://search.ebscohost.com/login.aspx?direct=true $\& \mathrm{db}=\mathrm{a} 9 \mathrm{~h} \& \mathrm{AN}=$ $12450982 \&$ site $=$ e host-live.

Lin,C.(2013).Using Literature Circles to Develop Critical Thinking Skills in a Senior High EFL Classroom in Taiwan, master 's thesis, National Chengchi University.

Maraccini, B. J.(2011). Teacher Perceptions of the Use of Literature Circles and Student Engagement in Reading. Doctor of Education, Piedmont College School of Education, Florida Atlantic University. Available

at: http://gradworks.umi.com/35/18/3518832.html.

Marshall,J.C.(2006). The Effects of Participation in Literature Circles on Reading Comprehension. Doctor of Philosophy, University of Miami, Coral Gables, Florida. Retreived July10, 2014 from: ProQuest Dissertation and Theses Database.

Martinez-Roldan, C. M., \& Lopez-Robertson, J. M. (2000). Initiating literature circles in a first-grade bilingual classroom. Reading Teacher, 53(4), 270-281.

McElvain, C. (2010). Transactional literature circles and the reading comprehension of English learners in the mainstream classroom. 
Journal of Research in Reading, 33(2), 178-205. doi: 10.1111/j.1 467-9817.2009.01403.x.

Medrano, E. D. (2013). An Investigation of Literature Circles as a Means to Promote Reading Comprehension. Doctor OF Philosophy, Faculty of Texas Tech University. Available at: https://repositories.tdl.org/ttu-ir/handle/2346/50624.

Murphy, P. K., Wilkinson, I. A. G., Soter, A. O., Hennessey, M. N. \& Alexander, J. F. (2009). Examining the effects of classroom discussion on students' high-level comprehension of text: A metaanalysis. Journal of Educational Psychology, 101, 740-764.

National Center for Educational Statistics. (2005). 2009 NAEP reading framework. Washington DC: Author.

Nolasco,J.(2009). Effects of Literature Circles on the Comprehension of Reading Expository Texts. Master of Arts, Graduate Program Caldwell College. Retreived July 13,2014 from: ProQuest Dissertation and Theses Database (UMI No. 1463936).

Olsen, A. (2007). Literature circles and ninth-grade students: A studentcentered approach to reading. Master of Science in Education, Southwest Minnesota State University. Retreived september 7,2014 from:ProQuest Dissertation and Theses Database (UMI No. 1443826).

Paris, S.G., \& Hamilton, E.E. (2008). The development of children's reading comprehension. In Israel, S. E\& ‘. Duffy, G., G. (Eds.). Handbook of research on reading comprehension (pp. 32-53). Manwah, NJ: Erlbaum.

Pitman, M. (1997). Literature circles. (ERIC Document Reproduction Service No.ED416503).

Prillaman, B. (2008). Conversations to help make meaning: ELLS and literature circles (Doctoral Dissertation). The University of Delaware. Retreived May5, 2012 from: ProQuest Dissertation and Theses Database (UMI No. 3291687).

Raman, M. (2004). English Reading Teaching. New Delhi: Atlantic Publisher and Distributers.

Rascher, S. (2015). The Effect of Literature Circles on the Reading Comprehension Scores of Middle School Students with Decoding Deficits. Master of Education, Graduate Programs in Education, Goucher College. Available at: https://mdsoar.org/bitstream/handle/11603/1702/MEd RascherSam antha_actionres_Fa2014.pdf?sequence $=1$. 
Reichert, R. (2005). Scientific Discovery Learning with Computer Simulations of Conceptual Domains of learning. Reviewed from www.elearning-reviews.org/publications/270 HTML.

Reid, S. (2002). Book Bridge for ESL students: Using young adult literature and children literature to teach ESL. Lanham, MD: Scarecrow Press.

Sai, M., \& Hsu, J. (2007). Multiple Intelligence literature circles. A JFL and EFL Experience. National Kaohsiung First University of Science \& Technology (ERIC Document Reproduction Service No.ED495304).

Salata, A. (2015). Using Literature Circles to Increase Participation and Reading Comprehension with Special Education Students. Master of Arts, Program of Special Education, Caldwell University. Retreived June 29, 2017 from: ProQuest Dissertation and Theses Database (UMI No. 1587454).

Slavin, R. E., \& Smith, D. (2009). The relationship between sample sizes and effect sizes in systematic review in education. Educational Evaluation and Policy Analysis, 31(4), 500-506.1

Sousa,T.(2011).Using Literature Circles to Increase Reading Comprehension Skills Among Sixth Grade Students. Masters of Arts, Graduate Program Caldwell College. Retreived July 21, 2016 from: ProQuest Dissertation and Theses Database (UMI No. 1492196).

Stabile, C. (2009) ". Arte Literature Circles an Effective Reading Strategy for Struggling Readers?.. Master 's thesis. Faculty of Education.Ohio University. Standard vs. Dramatic/ Technologically - Enhanced Literature Circle of Graduate Studies. York University.

Stein, D. \& Beed, P. (2004). Bridging the gap between fiction and nonfiction in the literature circle setting. The Reading Teacher, 57(6), 510-518. Retrieved from ERIC database.

Tomlinson, C. A., \& Strickland, C. A. (2005). Differentiation in practice: A resource guide for differentiating curriculum. Alexandria, VA: The Association for Supervision and Curriculum Development.

Tracey, D., \& Morrow, L. M. (2006). Lenses on reading: An introduction to theories and models. New York, NY: Guilford Press.

Vaughn, S., Klingner, J. K., Swanson, E. A., Boardman, A. G., Roberts, G., Mohammed, S. S., \& Stillman-Spisak, S. J. (2011). Efficacy of 
collaborative strategic reading with middle school students. American Educational Research Journal, 48 (4), 938-964.

Whittaker, C. R. (2012). Integrating literature circles into a cotaught inclusive classroom. Intervention in School and Clinic, 47(4), 214223.

Zeger N. (2006). "Classroom dialogue during literature response group", Language Arts, 66, 192-200.

Zieger, J. (2002). Literature circles. Teachers.net Gazette. Retrieved from August 10, 2007, from http://teachers.net/gazette/MAR02/zeiger.html. 